\title{
UJI ADAPTASI BEBERAPA VARIETAS PADI SAWAH (Oryza sativa L) DAN KAPUR DOLOMIT PADA TANAH GAMBUT
}

\author{
Adaptation Test of Several Varieties of Rice (Oryza sativa $L$ ) and \\ Dolomit Lime on Peatland
}

\author{
Hercules Gultom dan Mardaleni \\ FakultasPertanianUniversitas Islam Riau Jl. KaharuddinNasution No.113 Pekanbaru 28284 \\ Telp: 0761-72126 ext. 123, Fax: 0761-674681 Email: mardaleni@ymail.com \\ [Diterima Februari 2014, Disetujui Juli 2014]
}

\begin{abstract}
Adaptation test of several rice varieties and dolomit lime on peatland was carried out in the greenhouse of Faculty of Agriculture Riau Islamic University Pekanbaru. The purpose of this research ws to know adaptation power several yielding rice varieties on peatland with using dolomit and to obtain yielding rice varieties which is able to adapt with peatland, and to find a correct dosage by using doomit lime for raise $\mathrm{pH}$ soil. The experiment was arranged with grouply randomized design with two factors. The first factor was yielding rice varieties, consisting of four factors: V1 (IR 64), V2 (IR-72), V3 (Kapuas), and V4 (Santani). The second factor was dolomit lime, consisting of four factors: d1 (2.56 t/ha) and PH 5.6, D2 (3.60 t/ha and pH 5.4, D3 (4.51 t/ha) and pH 5.2, and D4 $(5.49 \mathrm{t} / \mathrm{ha})$ and $\mathrm{pH}$ 5.0. The parameter observed were plant height, number of productive shoot, percetage of unhask full rice, weight of dry rice per hectare, and weight of 1000 seeds. The resuts showed interaction using several yielding rice varieties was not significant effect on the observed parameters. However, the use of yielding varities showed a significant effect with the best variety: V1 (3.9 t/ha), V2 (3.8 t/ha), V3 (3.1 t/ha), and V4 (3.1 t/ha). While, the use of dolomit lime was affected significantly for the whole parameters with the best parameter: D1 (3,6 t/ha), D2 (3,6 t/ha), D3 (3,4 t/ha), and D4 (3,3 t/ha).
\end{abstract}

Keywords: Rice variety, Dolomit lime, Peatland

\begin{abstract}
ABSTRAK
Uji adaptasi beberapa varietas padi sawah dan kapur dolomit pada tanah gambut telah dilaksanakan di rumah kaca Fakultas Pertanian Universitas Islam Riau Pekanbaru. Tujuan penelitian ini untuk mengetahui daya adaptasi beberapa varietas unggulan padi pada tanah gambut dengan penggunaan dolomit dan untuk mendapatkan varietas unggulan padi yang mampu beradaptasi dengan tanah gambut, serta untuk mendapatkan dosis yang tepat penggunaan kapur dolomit untuk menaikkan $\mathrm{pH}$ tanah. Penelitian ini menggunakan metode Eksperiment dirancang dengan Rancangan Acak Kelompok (RAK) faktorial yang terdiri dari 2 faktor. Faktor pertama varietas unggulan, yang terdiri dari 4 taraf, yaitu: V1 (IR-64), V2 (IR-72), V3 (Kapuas) dan V4 (Sentani). Sedangkan Faktor kedua kapur dolomite, yang terdiri dari 4 taraf yaitu: D1 (2,56 t/ha) pH 5.6, D2 (3,60 t/ha) pH 5.4, D3 $(4,54 \mathrm{t} / \mathrm{ha}) \mathrm{pH} 5.2$, D4 (5,49 t/ha) $\mathrm{pH}$ 5.0. Paramater yang diamati adalah tinggi tanaman, jumlah anakan produktif, persentase gabah bernas, berat gabah kering/ha dan berat 1000 butir. Hasil penelitian menunjukkan bahwa interaksi penggunaan beberapa varietas unggulan tanaman padi tidak berpengaruh terhadap parameter yang diamati. Akan tetapi, penggunaan varietas unggul menunjukkan pengaruh yang nyata dengan varietas yang terbaik terdapat pada perlakuan V1 $(3,9$ t/ha), V2 (3,8 t/ha), V3 (3,1 t/ha), and V4 (3,1 t/ha). Sementara penggunaan pupuk dolomite juga berpengaruh nyata untuk semua parameter dengan perlakuan terbaik adalah D1 (3,6 t/ha), D2 (3,6 t/ha), D3 (3,4 t/ha), dan D4 (3,3 t/ha).
\end{abstract}

Kata Kunci: Varietas padi sawah, Kapur dolomit, Tanah gambut, Pertumbuhan, Produksi 


\section{PENDAHULUAN}

Penggunaan varietas-varietas unggul padi yang telah dilepas memiliki keunggulan dan kelemahan. keunggulan suatu varietas bila ditanami secara meluas baik pada tanah mineral secara terus menerus cenderung semakin berkurang keunggulannya. Sama halnya dengan varietas IR-64 yang paling banyak ditanami petani, selama kurang waktu tahun 1984 sampai sekarang varietas ini memiliki yang cukup tinggi dengan produksi $2-5$ t/ha serta tahan terhadap hama dan penyakit.

Perubahan suatu varietas terhadap suatu lahan pertanian yang berbeda tentu mempunyai masalah, pada umumnya varietas unggul selalu diarahkan pada lahan sawah yang mempunyai $\mathrm{pH}$ rendah, akan tetapi pemilihan suatu varietas untuk lahan gambut petani sering kali didasarkan kepada: potensi hasil yang rendah, tingkat ketahanan terhadap hama dan penyakit, umur panen dan kualitas gabah yang dihasilkan.

Harahap (1982) mengemukakan uji adaptasi beberapa varietas padi sawah dapat menunjang pelepasan varietas-varietas padi unggul baru khususnya pada lahan gambut. Dimana kita ketahui bahwa Riau memiliki lahan gambut yang cukup luas hampir $58,81 \%$ dari lahan yang tersedia. Namun pembangunan pertanian untuk lahan gambut belum dimanfaatkan secara intensif. Dalam pemanfaatan gambut mempunyai banyak kendala, baik dari sifat kimia maupun biologinya, sehingga kandungan unsur hara makronya lebih rendah terutama unsur $\mathrm{N}, \mathrm{P}$ dan $\mathrm{K}$. pH tanah yang rendah dimana kandungan $\mathrm{Fe}$ dan $\mathrm{Al}$ yang tinggi sehingga dapat meracun bagi tanaman. Sedangkan faktor biologisnya kurang aktivitas mikroorganisme didalam tanah sehingga proses dikomposisi bahan organic relative lambat.

Guna mengatasi permasalahan terhadap lahan gambut tersebut, dapat dilakukan perbaikan sifat-sifat kimianya yang erat hubungannya dengan ketersediaan unsur hara bagi tanaman padi sawah. Hal ini dapat dilakukan dengan menggunakan pengapuran, sehingga keasaman tanah akan berkurang. Salah satu kapur pertanian yang banyak digunakan adalah kapur dolomite $\left(\mathrm{CaMg}\left(\mathrm{CO}_{3}\right)_{2}\right)$ yang merupakan salah satu kapur yang digunakan guna menetralkan keasaman tanah, khusunya pada tanah gambut.
Hakim (1986) mengemukakan bahwa ketersediaan fosfor sangat tergantung kepada keasaman tanah, apabila $\mathrm{pH}$ rendah maka terjadi fiksasi P (fosfor) oleh unsur $\mathrm{Al}$ dan $\mathrm{Fe}$ dimana kedua senyawa ini akan membentuk senyawa hidroksi fosfat yang tidak larut.

Hal inilah yang menyebabkan lahan gambut sering kali terjadi kegagalan dalam pembudidayaan tanaman khususnya tanaman padi sawah, namun dalam segi pembudidayaan pada lahan gambut tidak mempunyai masalah yang serius karena untuk mengatasi masalah tersebut masih dapat dilakukan perbaikan dan juga pembudidayaan pada lahan gambut, hanya tergantung pada sistem yang dilakukan dalam pengairan teknis maupun non teknis.

Berdasarkan permasalahan tersebut, maka perlu adanya pengujian terhadap beberapa varietas tanaman padi sawah unggulan terhadap lahan gambut, sehingga didapat varietas yang mampu beradaptasi secara baik vegetatifnya maupun generative khususnya komponen hasil yang termasuk komponen bobot gabah kering, sehingga hasil penelitian ini dapat memberikan informasi yang bermanfaat dalam pembangunan pertanian khususnya tanaman padi sawah, sehingga pembudidayaan tidak lagi didominasi pada tanah mineral dalam bentuk sawah ataupun padi gogo/gogo rancah pada tanah mineral khusunya pada lahan kering.

\section{METODE PENELITIAN}

Penelitian dilaksanakan di Rumah Kaca Fakultas Pertanian Universitas Islam Riau. Penelitian dimulai bulan Januari sampai Juni 2012.

Bahan yang digunakan dalam penelitian ini adalah benih unggul varietas IR-64, IR-72, Kapuas dan Sentani, pupuk urea, TSP, KCl, insektisida diazianon, fungisida dithane M-45 serta curater. Sedangkan alat-alat yang digunakan adalah ember plastic, gembor, cangkul, hand sprayer kecil, meteran, timbangan dan alat tulis lainnya.

Penelitian ini menggunakan metode Eksperiment desing dan Rancangan Acak Kelompok (RAK) faktorial yang terdiri dari 2 faktor. Faktor pertama varietas unggulan, yang terdiri dari 4 taraf, yaitu: V1 (IR-64), V2 (IR72), V3 (Kapuas), V4 (Sentani). Sedangkan Faktor kedua kapur dolomite, yang terdiri dari 4 taraf yaitu: D1 (2,56 t/ha) pH 5.6, D2 (3,60 t/ha) 
$\mathrm{pH}$ 5.4, D3 (4,54 t/ha) pH 5.2, D4 (5,49 t/ha) $\mathrm{pH}$ 5.0 .

Pelaksanaan penelitian dimulai dari persiapan tempat, persiapan bibit, persiapan media tumbuh, pemberian pupuk urea, TSP, $\mathrm{KCl}$, perlakuan kapur dolomit dan penanaman. Paramater yang diamati adalah tinggi tanaman, jumlah anakan produktif, persentase gabah bernas, berat gabah kering/ha serta berat 1000 butir.

\section{HASIL DAN PEMBAHASAN}

\section{Tinggi Tanaman}

Tinggi tanaman pada akhir penelitian dengan perlakuan beberapa varietas unggul dan dosis kapur dolomit pada Tabel 1, kemudian data dianalisa sidik ragam dan uji lanjut Beda Nyata Jujur pada taraf nyata $5 \%$.

Pada Tabel 1 terlihat bahwa interaksi perlakuan antara uji adaptasi beberapa varietas unggul dan dosis kapur dolomit tidak berpengaruh sesama perlakuan, demikian juga varietas yang di uji juga tidak memperlihatkan adanya perbedaan terhadap tinggi tanaman. Hal ini terjadi karena masing-masing varietas unggul memiliki daya adaptasi yang luas terhadap lingkungan serta respon terhadap penggunaan kapur.

Akan tetapi dengan perlakuan kapur dolomit, terlihat adanya pengaruh penggunaan kapur dolomit, dimana D1 dan D2 berbeda nyata dengan perlakuan D3 dan D4. Hal ini membuktikan bahwa kapur dolomit yang diberikan pada dosis 4,54 tha dengan $\mathrm{pH}$ tanah 5,2 dan kapur dolomit 5,49 t/ha dengan $\mathrm{pH}$ tanah 5,0. Akan tetapi pada perlakuan D1 kebutuhan kapur 2,56 t/ha dengan $\mathrm{pH}$ tanah 5,6 dan $\mathrm{D} 2$ dosis kapur dolomit 3,6 t/ha dengan $\mathrm{pH}$ tanah 5,4.

Hakim (1986) mengemukakan bahwa keasaman tanah sangat berpengaruh terhadap ketersediaan hara tanaman, dimana keasaman tanah dibawah $\mathrm{pH}$ 5,6 adanya kekurangan kation basa yang dapat dipertukarkan pada $\mathrm{pH}$ yang rendah, namun demikian adanya kapur berarti penambahan kation-kation dalam jumlah yang sangat terbatas.

Dari keempat perlakuan kapur tersebut, terlihat bahwa D1 dan D2 merupakan yang terbaik yang dapat mempengaruhi dan menurunkan keasaman tanah secara cepat walaupun pada awalnya kondisi $\mathrm{pH}$ yang cukup berbeda, akan tetapi pada perlakuan tersebut menunjukkan yang terbaik atau dengan pengertian senyawa kalsium dan magnesium yang mempunyai pengaruh besar secara langsung dari kalsium karbonat dan kalsium oksida terhadap keasaman tanah, demikian juga reaksi pada perlakuan tersebut lebih cepat.

Setiono (1983) mengemukakan bahwa pengaruh pemberian kapur kedalam tanah dimana kalsium merupakan kation yang sering dihubungkan dengan keasaman tanah disebabkan dapat mengurangi efek keasaman. Disamping itu juga memberikan efek yang menguntungkan terhadap sifat tanah pada tanahtanah daerah basa, kalsium bersama-sama dengan hidrogen merupakan kation yang dominan pada absorbsi.

\section{Jumlah Anakan Produktif}

Jumlah anakan per rumpun pada tanaman padi sawah pada akhir pengamatan dapat dilihat pada Tabel 2. Kemudian data tersebut di analisis secara statistic dengan uji lanjut BNJ pada taraf $5 \%$.

Pada Tabel 2 terlihat bahwa interaksi atau hubungan antara varietas dengan penggunaan dosis kapur dolomit tidak berpengaruh nyata terhadap jumlah anakan produktif, namun perlakuan secara tunggal penggunaan dosis kapur dolomit berpengaruh nyata dimana yang terbaik pada perlakuan D1 dan D2 dan berbeda nyata dengan perlakuan D3 dan D4. Sehingga

Tabel 1. Tinggi Tanaman Padi Dengan Perlakuan Uji Adaptasi Beberapa Varietas Padi Sawah dengan Dosis Kapur Dolomit Pada Tanah Gambut

\begin{tabular}{cccccc}
\hline \multirow{2}{*}{ Kapur dolomit } & \multicolumn{4}{c}{ Varietas unggul } & \multirow{2}{*}{ Rerata } \\
\cline { 2 - 4 } & $\mathrm{V} 1$ & $\mathrm{~V} 2$ & $\mathrm{~V} 3$ & $\mathrm{~V} 4$ & $82.25 \mathrm{a}$ \\
D1 & 78.50 & 82.15 & 85.00 & 85.45 & $81.32 \mathrm{a}$ \\
D2 & 78.00 & 82.00 & 83.00 & 84.30 & $80.36 \mathrm{~b}$ \\
D3 & 77.45 & 81.20 & 82.30 & 82.50 & $80.02 \mathrm{~b}$ \\
D4 & 76.90 & 80.00 & 81.00 & 82.40 & 83.41 \\
\hline Rerata & 77.71 & 80.83 & 82.57 & \\
\hline KK = 5.45\% & \multicolumn{7}{c}{} \\
\hline Angka-angka yang diikuti oleh huruf kecil yang sama tidak berbeda nyata pada uji lnjut BNJ pada taraf nyata 5\%
\end{tabular}


Tabel 2. Jumlah Anakan Produktif dengan Perlakuan Uji Adaptasi Beberapa Varietas Padi Sawah dengan Dosis Kapur Dolomit Pada Tanah Gambut

\begin{tabular}{cccccc}
\hline \multirow{2}{*}{ Kapur dolomit } & \multicolumn{4}{c}{ Varietas unggul } & \multirow{2}{*}{ Rerata } \\
\cline { 2 - 4 } & $\mathrm{V} 1$ & $\mathrm{~V} 2$ & $\mathrm{~V} 3$ & $\mathrm{~V} 4$ & $12.65 \mathrm{a}$ \\
D1 & 14.00 & 14.00 & 11.50 & 11.00 & $12.05 \mathrm{a}$ \\
D2 & 13.00 & 13.20 & 11.00 & 11.00 & $10.68 \mathrm{~b}$ \\
D3 & 11.00 & 11.25 & 10.00 & 10.50 & $10.75 \mathrm{~b}$ \\
D4 & 10.00 & 11.00 & 11.00 & 11.00 & $10.87 \mathrm{~b}$ \\
\hline Rerata & $12.00 \mathrm{a}$ & $12.36 \mathrm{a}$ & $10.87 \mathrm{~b}$ & & \\
\hline
\end{tabular}

$\mathrm{KK}=5.60 \%$

Angka-angka yang diikuti oleh huruf kecil yang sama tidak berbeda nyata pada uji lnjut BNJ pada taraf nyata 5\%

jelas dengan pemberian kapur dolomit dengan dosis 2,65 ton/ha dengan $\mathrm{pH} 5,6$ serta perlakuan D2 3,60 ton/ha dengan $\mathrm{pH} 5,4$ memberikan peningkatan jumlah anakan.

Dalam pemberian dosis tersebut dimana dosis pada perlakuan D3 (4,54 ton/ha dengan $\mathrm{pH} 5,2)$ dan $\mathrm{D} 4(5,49$ ton/ha dengan $\mathrm{pH} 5,0)$ tidak menunjukkan peningkatan jumlah anakan pada tanaman padi. Hal ini menunjukkan tidak terjadinya peningkatan pada perlakuan ini disebabkan karena varietas tersebut tidak respon dengan pemberian kapur dolomit serta keasaman tanah masih dalam level pH 5,5 untuk ketersediaan unsure hara yang optimum terdapat pada $\mathrm{pH} 5,8$, sedangkan pada perlakuan D3 dan D4 masih dibawah pH 5,8 sehingga hara untuk tanaman masih terbatas terutama unsure $\mathrm{N}, \mathrm{P}$ dan $\mathrm{K}$ yang tidak dapat meningkatkan luas daun dan fotosintesa untuk jumlah anakan produktif.

Demikian juga untuk penggunaan varietas unggul, dimana pada perlakuan V1 IR-64 dan V2 IR-72 juga berpengaruh terhadap jumlah anakan produktif, bila dibandingkan dengan perlakuan V3 (Kapuas) dan V4 (Sentani) dalam hal ini bahwa varietas unggul lebih luas terhadap adaptasi lingkungan serta sangat respon terhadap pemberian kapur dolomit. Arifin dkk (1998) mengemukakan bahwa untuk mendapatkan varietas unggul, untuk mendapatkan varietas tersebut lebih luas terhadap adaptasi serta tahan terhadap hama dan penyakit yang pada gilirannya meningkatkan produksi.

\section{Persentase Gabah Bernas (\%)}

Persentase gabah bernas pada tanaman padi dengan perlakuan uji adaptasi beberapa varietas dan dosis kapur dolomit pada lahab gambut pada akhir pengamatan dapat dilihat pada Tabel 3. Kemudian data di analisa sidik ragam secara statistic dengan uji lanjut beda nyata jujur (BNJ) pada taraf $5 \%$.

Pada Tabel 3 dapat dilihat bahwa interaksi antara penggunaan kapur dolomit tidak berpengaruh terhadap persentase gabah bernas, akan tetapi secara tunggal pemberian kapur dolomit berpengaruh nyata, dimana perlakuan D1 $(2,64$ t/ha dengan $\mathrm{pH} \mathrm{5,6)}$ dan D2 $(3,60$ ton/ha dengan $\mathrm{pH} 5,4)$ berbeda nyata dengan perlakuan D3 (4,54 t/ha dengan $\mathrm{pH} 5,2)$ dan D4 $(5,49 \mathrm{t} / \mathrm{ha}$ dengan $\mathrm{pH} 5,0)$. Perlakuan yang terbaik adalah D1 dan D2. Hal ini karena pada perlakuan tersebut kondisi $\mathrm{pH}$ tanah sudah mencapai pH 5,9-6,5.

Kondisi pH pada 5,9 hingga 6,5 merupakan kondisi yang cukup baik dalam ketersediaan unsure hara makro dan mikro, apabila unsur tersebut dapat diserap oleh tanaman dalam jumlah yang cukup, maka produksi tanaman akan meningkat.

Pada perlakuan D3 dan D4 adanya

Tabel 3. Persentase gabah Bernas dengan Perlakuan Uji Adaptasi Beberapa Varietas Padi Sawah Dengan Dosis Kapur Dolomit Pada Tanah Gambut

\begin{tabular}{|c|c|c|c|c|c|}
\hline \multirow{2}{*}{ Kapur dolomit } & \multicolumn{4}{|c|}{ Varietas unggul } & \multirow[t]{2}{*}{ Rerata } \\
\hline & V1 & $\mathrm{V} 2$ & V3 & V4 & \\
\hline D1 & 90.25 & 90.00 & 85.60 & 84.00 & $87.46 \mathrm{a}$ \\
\hline D2 & 89.00 & 90.30 & 85.00 & 85.00 & $85.82 \mathrm{a}$ \\
\hline D3 & 85.60 & 83.00 & 84.25 & 84.25 & $84.27 \mathrm{~b}$ \\
\hline $\mathrm{D} 4$ & 85.00 & 82.25 & 83.00 & 83.45 & $82.92 \mathrm{~b}$ \\
\hline Rerata & $87.46 \mathrm{a}$ & $86.38 \mathrm{a}$ & $84.46 \mathrm{~b}$ & $84.17 \mathrm{~b}$ & \\
\hline $\mathrm{KK}=3.80 \%$ & & & & & \\
\hline
\end{tabular}


penurunan persentase gabah bernas, penurunan ini disebabkan karena kapur yang diberikan untuk menaikkan $\mathrm{pH}$, tidak tercapai pada keadaan yang diharapkan. Gultom (1996) mengemukakan bahwa adanya penurunan persentase gabah bernas, juga dipengaruhi tidak terserapnya unsure hara makro terutama unsur nitrogen, dimana kita ketahui unsur ini sangat penting karena nitrogen juga berperan dalam pembentuka protein serta sangat berperan dalam pembentukan butir hijau daun dalam proses fotosintesa. Apabila jumlah nitrogen yang cukup, maka proses perombakan amoniak akan disintesa menjadi protein dan amoniak atau asam amino untuk bahan kering tanaman termasuk gabah bernas.

\section{Berat Gabah Kering}

Hasil berat gabah kering/ha pada akhir penelitian dengan perlakuan uji adaptasi beberapa varietas unggulan dan dosis kapur dolomit pada lahan gambut dapat dilihat pada Tabel 4.

Pada Tabel 4 dapat dilihat bahwa interaksi perlakuan uji adaptasi penggunaan beberapa varietas unggul dan kapur dolomit tidak berpengaruh nyata terhadap produksi gabah kering, akan tetapi secara tunggal perlakuan kapur dolomit memperlihatkan perbedaan yang nyata terhadap hasil. Dimana hasil tertinggi terdapat pada perlakuan D1 (2,65 ton/ha dengan $\mathrm{pH} 5,6)$ dan $\mathrm{D} 2(3,60$ ton/ha dengan $\mathrm{pH} 5,4)$.

Menurut Setiono (1983) perubahan kapur didalam tanah dan mempunyai efek yaitu efek fisik dimana kecenderungan zarah harus berasosiasi terlalu rapat serta struktur remah dan juga adanya gaya-gaya biotik sangat terkenal terutama yang mempengaruhi dekomposisi bahan organik dan pembentukan humus. Sedangkan pada efek kimia adalah dapat menaikkan $\mathrm{pH}$ dan juga efek secara tidak langsung terhadap tersedianya hara dan dapat terhindar dari keracunan beberapa unsur misalnya unsur $\mathrm{Al}$ dan $\mathrm{Fe}$, dan efek biologinya dimana pemberian kapur dapat merangsang kegiatan organisme tanah tanah dengan demikian meningkatkan arti bahan organik dan nitrogen.

Demikian juga dengan penggunaan varietas unggul adanya perbedaan diantara empat varietas unggul yang di uji, masingmasing telah beradaptasi secara baik dan ini dilihat dari produksi gabah kering per ha. Akan tetapi, varietas unggul IR-64 dan IR-72 masih menunjukkan adaptasi yang lebih luas baik dari penyerapan unsur hara serta faktor lingkungan.

Siwi (1983) mengemukakan bahwa salah satu kelebihan dari varietas unggul selain mempunyai adaptasi yang kuat juga memiliki ketahanan terhadap hama dan penyakit, terutama hama wereng coklat dan kresek, walaupun pada waktu yang tidak terbatas varietas ini nantinya akan lebih peka terhadap hama dan penyakit, namun pada saat dilakukan penelitian varietas unggul masih toleran terhadap hama dan penyakit.

Hardian (1987) juga mengemukakan bahwa varietas unggul memiliki potensi hasil yang tinggi, karena pada umumnya varietas tersebut memiliki adanya respon terhadap pemupukan terutama unsur nitrogen dan sangat toleran terhadap penyakit blast.

\section{Berat 1000 Butir}

Berat 1000 butir pada tanaman padi akhir pengamatan dapat dilihat pada Tabel 5 . Kemudian data dianalisa sidik ragam setelah itu dilanjutkan dengan uji lanjut Beda Nyata Jujur (BNJ) taraf 5\%.

Tabel 4. Hasil Berat Gabah Kering/Ha Pada Tanaman Padi dengan Perlakuan Uji Adaptasi Beberapa Varietas Padi Sawah dengan Dosis Kapur Dolomit Pada Tanah Gambut

\begin{tabular}{cccccc}
\hline \multirow{2}{*}{ Kapur dolomit } & \multicolumn{4}{c}{ Varietas unggul } & \multirow{2}{*}{ Rerata } \\
\cline { 2 - 5 } & $\mathrm{V} 1$ & $\mathrm{~V} 2$ & $\mathrm{~V} 3$ & $\mathrm{~V} 4$ & \\
\hline D1 & 4.20 & 4.30 & 3.20 & 3.00 & $\mathrm{a}$ \\
D2 & 4.10 & 4.00 & 3.30 & 3.10 & $3.60 \mathrm{a}$ \\
D3 & 3.80 & 3.70 & 3.00 & 3.10 & $3.40 \mathrm{a}$ \\
D4 & 3.60 & 3.50 & 3.10 & 3.20 & $3.30 \mathrm{~b}$ \\
\hline Rerata & $3.90 \mathrm{a}$ & $3.80 \mathrm{a}$ & $3.10 \mathrm{~b}$ & $3.10 \mathrm{~b}$ & \\
\hline KK = 3.15\% & & & & \\
\hline
\end{tabular}

Angka-angka yang diikuti oleh huruf kecil yang sama tidak berbeda nyata pada uji lnjut BNJ pada taraf nyata 5\% 
Tabel 5. Berat 1000 Butir Per Rumpun Pada Tanaman Padi dengan Perlakuan Uji Adaptasi Beberapa Varietas Padi Sawah dengan Dosis Kapur Dolomit Pada Tanah Gambut

\begin{tabular}{|c|c|c|c|c|c|}
\hline \multirow{2}{*}{ Kapur dolomit } & \multicolumn{4}{|c|}{ Varietas unggul } & \multirow[t]{2}{*}{ Rerata } \\
\hline & V1 & $\mathrm{V} 2$ & V3 & V4 & \\
\hline D1 & 24.30 & 23.75 & 19.00 & 19.00 & $21.51 \mathrm{a}$ \\
\hline D2 & 24.00 & 24.15 & 18.54 & 18.50 & $21.29 \mathrm{a}$ \\
\hline D3 & 22.75 & 21.00 & 18.00 & 17.35 & $19.77 \mathrm{~b}$ \\
\hline D4 & 21.00 & 21.18 & 18.50 & 17.00 & $19.42 \mathrm{~b}$ \\
\hline Rerata & 23.01 & 22.52 & 18.51 & 17.96 & \\
\hline
\end{tabular}

$\mathrm{KK}=21.46 \%$

Angka-angka yang diikuti oleh huruf kecil yang sama tidak berbeda nyata pada uji lnjut BNJ pada taraf nyata 5\%

Pada Tabel 5 dapat dilihat bahwa interaksi perlakuan antara dosis kapur dolomit dan beberapa varietas unggul yang diuji memiliki adaptasi yang luas terhadap lahan gambut serta mempunyai kemampuan dalam mengantisipasi terhadap lingkungan.

Secara tunggal dimana pemberian dosis kapur dolomit berpengaruh terhadap dosis yang diperlakukan dimana yang terbaik pada perlakuan D1 $(92,65 \mathrm{t} / \mathrm{ha}$ dengan $\mathrm{pH} 5,6)$ dan D2 $(3,60 \mathrm{t} /$ ha dengan $\mathrm{pH} 5,4)$ hal ini terlihat bahwa kapur dolomit pada pH 5,4 sampai 5,6 dengan dosis kapur yang diberikan mampu menaikkan pH tanah sampai pada $\mathrm{pH}$ 5,8 dan pH6,5.

Lingga (1991) mengemukakan bahwa dengan pemberian kapur dolomit dimana kapur tersebut selain dapat menaikkan $\mathrm{pH}$ tanah juga dapat menyumbangkan unsur hara $\mathrm{Ca}$ dan $\mathrm{Mg}$, sehingga aktivitas dalam fotosintesa akan meningkat. Dimana unsur $\mathrm{Mg}$ merupakan bagian dari protoplast yaitu butirObutir hijau yang sangat penting dalam proses fotosintesa tersebut. Lebih jauh dikemukakan oleh Hakim (1986) dengan pemberian kapur dolomit dapat memperbaiki sifat fisik, kimia dan biologi tanah. Dimana sifat fisik tanah berat selalu cenderung zarah halus, dari segi efek kimia dimana $\mathrm{pH}$ dapat naik yang dapat mempengaruhi yaitu konsentrasi ion hidrogen akan menurun, konsentrasi ion hidrosil akan naik serta daya larutan $\mathrm{Al}$ dan $\mathrm{Fe}$ menurun sehingga keter-sediaan unsure fosfor akan meningkat dan molibdenum.

Pada perlakuan D3 (4,54 t/ha dengan $\mathrm{pH}$ $5,2)$ dan $\mathrm{D} 4(5,49 \mathrm{t} / \mathrm{ha}$ dengan $\mathrm{pH} 5,0)$ pada akhir penelitian $\mathrm{pH}$ tersebut masih dalam lingkungan antara $\mathrm{pH}$ 5,6-5,7 sehingga dalam penyerapan hara masih terbatas. Menurut Bunchman dan Brandy (1982) bahwa unsure hara yang esensial tersedia dalam kisaran $\mathrm{pH}$ 5,8-6,5 hingga $\mathrm{pH}$ netral yaitu 7,0. Akan tetapi, dalam penelitian ini, $\mathrm{pH}$ tersebut belum menapai pada titik yang diharapkan sehingga berat 1000 butir masih rendah bila dibandingkan dengan perlakuan D1 dan D2.

Demikian juga dengan penggunaan varietas unggul, adanya berbedaan diantara varietas yang diuji, dimana yang terbaik pada perlakuan V1 (IR-64) dan V2 (IR-72) adaptasi kedua varieta ini cukup luas bila dibandingkan dengan V3 (Kapuas) dan V4 (Sentani).

Arifin dkk (1998) menjelaskan bahwa keunggulan suatu varietas bila ditanam pada waktu tertentu memiliki kemampuan yang cukup, akan tetapi kita jangan lupa bahwa varietas unggul suatu saat keunggulan varietas ini akan turun, artinya ditanam terus menerus secara intensif cenderung semakin berkurang, baik ketahanan terhadap hama dan penyakit maupun ketahanan dalam mengantisipasi lingkungan yang menyebabkan potensi hasilnya juga akan berkurang.

\section{KESIMPULAN}

Dari hasil penelitian yang telah dilakukan dapat diambil kesimpulan sebagai berikut:

1. Perlakuan interaksi penggunaan varietas unggul dan dosis penggunaan kapur dolomit tidak berpengaruh terhadap parameter yang diamati.

2. Perlakuan dosis kapur dolomit memberikan pengaruh terhadap parameter yang diamati, dimana yang terbaik pada perlakuan D1 $(2,65 \mathrm{t} / \mathrm{ha}) \mathrm{pH} 5,6$ dengan produksi 3,6 t/ha yang diikuti perlakuan D2 (3,60 t/ha) $\mathrm{pH} 5,4$ dengan produksi 3,6 t/ha.

3. Perlakuan penggunaan varietas unggul juga memberikan pengaruh terhadap parameter yang diamati, dimana yang terbaik adalah V1 (IR-64) produksi 3,9 t/ha dan diikuti perlakuan V2 (IR-72) produksi 3,8 t/ha. 
DAFTAR PUSTAKA

Arifin, Z. 1998. Uji Adaptasi Galur Harapan Padi Sawah Berumur Genjah dan Berumur Sedang. Balai Pengkajian Teknologi Karang Ploso, Malang.

Buchman, H. O. dan C. B. Nyle. 1969. Ilmu Tanah Terjemahan Soegiman. 1982. Brata Karya Aksara. Jakarta.

Setiono, E. 1983. Pengaruh Sisa Dolomit Terhadap Pertumbuhan dan Produksi Kedelai. Ringkasan Tesis Fakultas Pertanian IPB, Bogor.

Gultom, H. 1996. Budidaya Tanaman Padi. Universitas Islam Riau, Pekanbaru.
Hakim. 1986. Dasar-dasar Ilmu Tanah. Universitas Lampung. Bandar Lampung. Harahap, Z. 1982. Pedoman Pemuliaan Padi. Lembaga Biologi Nasional-LIPI, Bogor.

Hardian. 1987. Budidaya Tanaman Padi di Indonesia. Sastra Hudaya, Jakarta.

Lingga, P. 1991. Petunjuk Penggunaan Pupuk. PT. Penebar Swadaya, Jakarta.

Siwi, B. H. 1983. Penelitian Perbaikan Padi dan Palawija. Dalam Ismunadji et al (ed). Peranan hasil Penelitian Padi dan Palawija dalam Pembangunan Pertanian. Pusat Penelitian dan Pengembangan Tanaman Pangan, Bogor. 
